Available online at GSC Online Press Directory

GSC Biological and Pharmaceutical Sciences

e-ISSN: 2581-3250, CODEN (USA): GBPSC2

Journal homepage: https://www.gsconlinepress.com/journals/gscbps

(RESEARCH ARTICLE)

\title{
Studies on yield and yield attributes in tomato and chilli using foliar application of oligo-chitosan
}

\author{
Islam Md. Monirul 1*, Kabir Md. Humayun ${ }^{1}$, Mamun A.N.K ${ }^{1}$, Islam Monirul ${ }^{2}$, Islam Md. Monirul ${ }^{1}$ and Das \\ Pronabananda ${ }^{1}$ \\ ${ }^{1}$ Plant Biotechnology and Genetic Engineering Division, Institute of Food and Radiation Biology, Atomic Energy Research \\ Establishment, Ganakbari, savar, Dhaka-100, Bangladesh \\ 2 Department of Life Sciences and Systems Biology, Plant Physiology Unit, University of Turin, Via Quarello15/A, I-10135 \\ Turin, Italy ${ }^{2}$ Department of Biological Sciences, Taraba State University Jalingo, Nigeria
}

Publication history: Received on 15 May 2018; accepted on 11 June 2018

Article DOI: https://doi.org/10.30574/gscbps.2018.3.3.0038

\begin{abstract}
Chitosan is a very important linear polysaccharide used in agricultural and horticultural practices primarily for plant defense and yield increase in recent decades. In this study, four levels of oligochitosan were used with control to optimize the level for obtaining maximum yield in tomato and chilli. It was observed that in case of tomato50 ppm chitosan level was found optimum in terms of yield $(2.48 \mathrm{~kg} / \mathrm{plant})$. Positively linear correlation was also observed in leaves/plant (0.52), branch/plant (0.48), days to flowering (0.39) and fruit/plant (0.16) with the different levels of oligochitosan. The phenotypic coefficient of variance was found greater than the genotypic coefficient of variance. On the other hand, in case of chilli, 75 ppm chitosan level was found optimum in yield (333.01 g/plant). All the parameters of chilli i.e. plant height (49.36 cm), branch/plant (43.07), fruits/plant (151.86), fruit length $(19.20 \mathrm{~cm})$, fruit width $(1.06 \mathrm{~cm})$, the weight of 50 chilli $(199.11 \mathrm{~g})$ gave positive correlation with the different levels of oligochitosan. In case of yield, the phenotypic coefficient of variance was found greater than the genotypic coefficient of variance.
\end{abstract}

Keywords: Oligochitosan; Foliar spray; Yield; Tomato; Chilli

\section{Introduction}

Tomato (Lycopersicon esculentum Mill) is one of the most popular and nutritious vegetable crops and grown throughout the world as well as in Bangladesh. It belongs to the family Solanaceae. It ranks first among the vegetables and is a major source of carbohydrate, vitamin and minerals [1]. On the other hand, chilli (Capsicum annuum) is an important spice yielding plant and belongs to the family Solanaceae. It is a valuable and essential spice in our daily diet. The genus Capsicum native to South and Central America [2]. It is mainly used in the form of green, dried and powder. It becomes an essential ingredient in daily meals and usually used in all carry preparation like meat, fish, vegetables, pulses etc. for its typical color, taste and flavor [3]. It contains large amounts of vitamin $\mathrm{C}$ and a small amount of carotene and also volatile oil, fatty oils, capsaicinoids, protein, fiber and minerals [4]. The red color of tomato is due to lycopene and the yellow color is due to carotenes. The demand for tomato in our country is increasing day by day with the increase in population. The fruits are eaten as a salad, cooked vegetables in various ways like juice, ketchup, sauces, chutney etc. [5]. The yield of the tomato in the country is still low to those obtained in some advanced country in the world [6]. Although a number of local and improved varieties of tomatoes are being cultivated in Bangladesh but all of them has been suffering from various biotic and abiotic stresses [7-8]. Producing more tomato by increasing tomato producing

\footnotetext{
${ }^{*}$ Corresponding author

E-mail address: monirul.rubd@ gmail.com
}

Copyright (C) 2018 Author(s) retain the copyright of this article. This article is published under the terms of the Creative Commons Attribution Liscense 4.0. 
area in the country is not possible due to limitation of land. These plants are widely grown in Bangladesh usually in winter season (October-January).

In case of tomato, to date, about 75,602 acres of land is brought under cultivation and the production is about 4,13,610 MT and yield is about $5471 \mathrm{~kg} /$ acres and about 2, 27,754 acres of land is under chilli cultivation in Bangladesh and the production is about 1,22,848 MT and yield is about $1185 \mathrm{~kg} /$ acres [9]. At present, although the area and the production have been raised but per unit yield is still low comparing to other chilli growing countries in the world such as China, Turkey, Mexico, Spain, USA, Indonesia, Nigeria, Italy and India [10]. Per unit yield could be increased by supplying nutrients and other management practices. Chitosan is a biopolymer, a chitin derivative, a compound which is completely safe for the environment [11]. Chitin is a fibrous substance consisting of polysaccharides, which is the major constituent in the exoskeleton of shellfish such as shrimp, lobster or crabs and cell wall of fungi [12]. Few efforts were done to study the effect of chitosan on plant growth, development and productivity, which is mainly, attributed stimulation of plants immunity against microorganisms like bacteria and [13-15]. This compound is characterized by unique properties, such as bioactivity and bio-compatibility [16]. The results from the literature showed that, when chitosan is being used in plants, it reduces transpiration [17] and induces a range of metabolic changes as a result of which, plants become more resistant to viral, bacterial and fungal infections [18]. Moreover, plants treated with chitosan may be less prone to stress evoked by unfavorable conditions, such as drought, salinity, low or high temperature [1920]. Chitosan stimulates vital processes of plants on every level of biological process, from single cells and tissues, through physiological and biochemical processes, to changes on the molecular level related to expression of genes [2124]. Recently some researchers reported that chitosan enhanced key enzymes activities of nitrogen metabolism and improved the transportation of nitrogen in the functional leaves which enhance plant growth and development [25-26]. Considering the above facts, the present investigation was undertaken to study the effect of chitosan on growth and yield of tomato and chilli in winter season.

\section{Material and methods}

\subsection{Collection of seed and the location of study area}

Seeds were collected from the Lal Teer Seed Ltd., Bangladesh. To prevent some seed-borne diseases such as leaf spot, blight, anthracnose, etc., seeds were treated by Vitavax-200@ $5 \mathrm{~g}^{-1} \mathrm{~kg}^{-1}$ seed. Seedlings were grown in poly bags under shade house. About twenty days old seedlings were transplanted in the experimental field of Plant Biotechnology and Genetic Engineering Division (PBGED), Institute of Food and Radiation Biology (IFRB), Atomic Energy Research Establishment (AERE), Savar, Dhaka, during the period of November-March 2016.

\subsection{Experiment and treatment}

The experimental field was prepared by ploughing, harrowing and hand spade. The experimental plot size was $5.0 \times 2.0$ $\mathrm{m}^{2}$ and in case of tomato, plant to plant and row to row distance was maintained to $40 \mathrm{~cm} \times 60 \mathrm{~cm}$ whilst in chilli it was $30 \mathrm{~cm} \times 60 \mathrm{~cm}$. The experimental design was followed randomized complete block design (RCBD) with three replications. The physiochemical prosperities of soil in the experimental field are: $\mathrm{pH}=6.30$, sandy clay loam, soil organic carbon $0.60 \%$, soil organic matter $1.20 \%$, total nitrogen $0.25 \%$, available phosphorus $80 \mathrm{mg} / \mathrm{kg}$, available potassium 264 $\mathrm{mg} / \mathrm{kg}$, available sulphur $175 \mathrm{mg} / \mathrm{kg}$, calcium $648 \mathrm{mg} / \mathrm{kg}$, sodium $204 \mathrm{mg} / \mathrm{kg}$. For the tomato, recommended doses of fertilizer were urea @ 550 kg/ha, MP @250 kg/ha, cowdung @10 t/ha and in case of chilli recommended fertilizer doses of urea were @75 kg/ha, TSP@150 kg/ha and MP@200kg/ha. Full dose of cowdung, TSP, MP and one third (1/3) dose of urea were applied during land preparation and remaining dose of urea was applied during branching and fruiting stage. Intercultural operations such as irrigation, weeding etc. were done as and when necessary. Four (4) chitosan levels @25 ppm, 50 ppm, 75 ppm, and 100 ppm with control were used as treatments in these experiments. Chitosan was diluted with $1 \%$ acetic acid and converted into oligochitosan by gamma irradiation of $5 \mathrm{KGy}$ and was used for whole experiments. The different levels of oligochitosan were sprayed at three growth stages to tomato and chilli such as (a) vegetative stage (b) flowering stage and (c) fruiting stage in the morning by using hand sprayer. Oligochitosan application was done at each stage for five times at every alternate day. In case of Maize grain tomato, data were collected on days to flowering, plant height (cm), leaves/plant (no), Branch/plant (no), fruits/plant (no), average fruit weight (g) and yield/plant (kg).

\subsection{Measurement}

Plant height, leaf number and branches were measured on 40 days after planting and fruits number, fruits weight and the total yield/plant $(\mathrm{kg})$ were recorded during harvesting time.In case of chilli, data were collected on plant height 
(cm), branch/plant (no), fruit/plant (no), fruit length (cm), fruit width (cm), weight of $50 \mathrm{chillis}(\mathrm{g})$ and yield/plant (g) at the time of harvest.

\subsection{Statistical analysis}

The data were analyzed for the estimation of variance, linear correlation, F-value, p-value at $0.05 \%$ level by analysis of variance (ANOVA). Genotypic coefficient of variance (gcv) and phenotypic coefficient of variance (pcv) were estimated by using the formula, adopted from Burton and De vane (1953) and Johnson et al. 1955a and 1955b.The mean differences were adjusted with Duncan's Multiple Range Test (DMRT) using the statistical computer package program, MSTAT-C (Russell,1986).

\section{Results}

\subsection{Foliar application of chitosan in tomato}

The influence of oligochitosan at different concentrations with differential growth stages on yield and yield attributes were slightly increased comparing to control (table-1). The effect of different concentrations $(0,25,50,75$ and 100 ppm) of oligochitosan in tomato on days to flowering, plant height, leaves/plant, branch/plant, fruits/plant, average fruit weight and yield/plant was presented in Table-1. The present study indicated that foliar application at 50 ppm oligochitosan level played a positive role on yield in tomato. But the yield decreased, when the level of oligochitosan application was crossed beyond $50 \mathrm{ppm}$. The highest yield/plant (2.84 kg) of tomato was recorded with the application of $50 \mathrm{ppm}$ oligochitosan. Interestingly the maximum plant height and leaves/plant were obtained with the supplement of $100 \mathrm{ppm}$ oligochitosan. The highest number of branch/plant was showed with the application of 100 ppm oligochitosan whilst the lowest branch number was found at $25 \mathrm{ppm}$. In contrast, early flowering was observed with the application of $75 \mathrm{ppm}$ oligochitosan. It was obvious from the study that application of five different concentrations of oligochitosan obtained minor differences of flowering in plant. The highest number of fruit/plant was found at 50 ppm of oligochitosan comparing to other treatments studied.

Table 1 Effect of foliar application of chitosan on growth and yield of tomato

\begin{tabular}{|c|c|c|c|c|c|c|c|}
\hline $\begin{array}{l}\text { Level of } \\
\text { oligochitosa } \\
\text { n application } \\
\text { (ppm) }\end{array}$ & $\begin{array}{l}\text { Plant } \\
\text { height } \\
\text { (cm) }\end{array}$ & $\begin{array}{l}\text { Leaves/ } \\
\text { plant } \\
\text { (no.) }\end{array}$ & $\begin{array}{l}\text { Branches } \\
\text { / } \\
\text { plant }\end{array}$ & $\begin{array}{l}\text { Days to } \\
\text { flowerin } \\
\mathrm{g}\end{array}$ & $\begin{array}{l}\text { Fruits/plant } \\
\text { (no.) }\end{array}$ & $\begin{array}{l}\text { Average } \\
\text { fruit } \\
\text { weight } \\
\text { (g) }\end{array}$ & $\begin{array}{l}\text { Yield/ } \\
\text { plant } \\
\text { (kg) }\end{array}$ \\
\hline 0 & $99.42^{c}$ & 39.03 b & 5.51 bc & 39.28 b & $18.83^{c}$ & $97.86^{b}$ & $1.90 \mathrm{~b}$ \\
\hline 25 & $92.66^{d}$ & $28.94^{d}$ & $3.84^{d}$ & $42.45^{a}$ & $17.67 \mathrm{~d}$ & 79.88 е & $1.79 \mathrm{bc}$ \\
\hline 50 & $104.54 \mathrm{bc}$ & $40.36^{b}$ & $6.51^{b}$ & 38.49 b & $24.57^{a}$ & $102.11^{\mathrm{a}}$ & $2.48^{a}$ \\
\hline 75 & $103.96^{c}$ & $36.52^{c}$ & $4.16^{c d}$ & $42.48^{a}$ & $17.66^{d}$ & $92.08^{c}$ & $1.70 \mathrm{bc}$ \\
\hline 100 & $107.75^{\mathrm{a}}$ & $46.24^{\mathrm{a}}$ & $8.33^{a}$ & $42.35^{\mathrm{a}}$ & 20.83 b & $89.14^{d}$ & $1.58^{c}$ \\
\hline F-test & $* *$ & $* *$ & $* *$ & $* *$ & $* *$ & $* *$ & $* *$ \\
\hline CV\% & 1.77 & 3.27 & 4.25 & 3.64 & 2.76 & 0.28 & 6.65 \\
\hline
\end{tabular}

In table-1, it was also found that the number fruit/plant was 24.57 at $50 \mathrm{ppm}$ of oligochitosan application comparing to other levels of oligochitosan tested. The highest fruit weight/plant (102.11 g) was observed with the application of 50 ppm oligochitosan. The present findings indicate that the oligochitosan has positive effect in tomato yield. It is an evidence in this study. The lowest fruit yield was observed in control plants due to absence of oligochitosan. The decreasing trend of fruit yield and poor plant growth was found at oligochitosan level of $75 \mathrm{ppm}$ and $100 \mathrm{ppm}$ respectively, which might be due to toxic levels of oligochitosan or other unknown factors.

In table-2, the genotypic coefficient of variance (gcv) in case of plant height, leaves/plant, Branch/plant, days to flowering, fruits/plant, average fruit weight and yield/plant were observed $147.63 \mathrm{~cm}, 102.35,55.38,7.51,41.99,78.95$ g and $6.08 \mathrm{~kg}$ respectively. On the other hand the phenotypic coefficient of variance (pcv) for plant height, leaves/plant, 
branch/plant, days to flowering, fruits/plant, average fruit weight and yield/plant were found $150.97 \mathrm{~cm}, 106.44,66.84$, $13.04,43.50,79.02 \mathrm{~g}$ and $6.88 \mathrm{~kg}$ respectively.

Table 2 Study of PCV and GCV in tomato by foliar application of oligochitosan

\begin{tabular}{llllllll}
\hline & $\begin{array}{l}\text { Plant } \\
\text { height } \\
\text { (cm) }\end{array}$ & $\begin{array}{l}\text { Leaves/plant } \\
\text { (no.) }\end{array}$ & $\begin{array}{l}\text { Branches/ } \\
\text { plant }\end{array}$ & $\begin{array}{l}\text { Days to } \\
\text { flowering }\end{array}$ & $\begin{array}{l}\text { Fruits/plant } \\
\text { (no.) }\end{array}$ & $\begin{array}{l}\text { Average } \\
\text { fruit weight } \\
\text { (g) }\end{array}$ & $\begin{array}{l}\text { Yield } \\
\text { plant } \\
\text { (kg) }\end{array}$ \\
\hline $\mathrm{GCV} \%$ & 147.63 & 102.35 & 55.38 & 7.51 & 41.99 & 78.95 & 6.08 \\
$\mathrm{PCV} \%$ & 150.97 & 106.44 & 66.84 & 13.04 & 43.50 & 79.02 & 6.88 \\
\hline \multicolumn{7}{r}{$\mathrm{PCV}=$ Phenotypic co-efficient of variance; GCV = Genotypic co-efficient of variance }
\end{tabular}

In table-3, it was found that the treatments were negatively linear correlated with plant height, average fruit weight and yield/plant. The values of these parameters decreased due to the increasing levels of oligochitosan application. Average fruit weight was observed negatively very weak linear correlated with the treatments. On the other, hand plant height was found negatively weak linear correlated. Positively linear correlation was also found with the treatments of other parameters (table-3). Branch/plant and days to flowering showed positively moderate linear correlation. Fruits/plant was found positively very weak and leaves/plant showed positively moderate linear correlation.

Table 3 Study on correlation of oligochitosan with different parameters in tomato

\begin{tabular}{|c|c|c|c|c|c|c|c|c|}
\hline & $\begin{array}{l}\text { Treatment } \\
\text { (ppm) }\end{array}$ & $\begin{array}{l}\text { Plant } \\
\text { height } \\
\text { (cm) }\end{array}$ & $\begin{array}{l}\text { Leaves } \\
\text { /plant } \\
\text { (no.) }\end{array}$ & $\begin{array}{l}\text { Branches } \\
\text { /plant } \\
\text { (no.) }\end{array}$ & $\begin{array}{l}\text { Days to } \\
\text { flowering }\end{array}$ & $\begin{array}{l}\text { Fruits/ } \\
\text { plant } \\
\text { (no.) }\end{array}$ & $\begin{array}{l}\text { Average } \\
\text { fruit } \\
\text { weight } \\
\text { (g) }\end{array}$ & $\begin{array}{l}\text { Yield/ } \\
\text { plant } \\
\text { (kg) }\end{array}$ \\
\hline Treatment (ppm) & 1 & & & & & & & \\
\hline Plant height $(\mathrm{cm})$ & -0.335 & 1 & & & & & & \\
\hline leaves/plant (no.) & 0.5172 & 0.4026 & 1 & & & & & \\
\hline Branches/plant (no.) & 0.4801 & 0.2936 & 0.797 & 1 & & & & \\
\hline Days to flowering & 0.3958 & -0.281 & -0.203 & -0.056 & 1 & & & \\
\hline Fruits/plant (no.) & 0.1661 & 0.194 & 0.314 & 0.556 & -0.182 & 1 & & \\
\hline Average fruit weight (g) & -0.093 & 0.637 & 0.459 & 0.355 & -0.560 & 0.646 & 1 & \\
\hline Yield/plant (kg) & -0.211 & -0.182 & 0.120 & -0.108 & -0.713 & -0.102 & 0.227 & 1 \\
\hline
\end{tabular}

Correlation is an effect size and so we can verbally describe the strength of the Correlation using the guide that Evans (1996) suggests for the absolute value of r: (.00-.19 very weak; .20-.39 weak; .40-.59 moderate; .60-.79 strong; .80-1.0 very strong)

\subsection{Foliar application of chitosan in chilli}

The effect of different levels of oligochitosan on plant height, branch/plant, fruits/plant, fruit length, fruit width, weight of 50 chilli and yield/plant were presented in Table-4. This study showed that positive effect on yield and yield attributes was found in case of foliar application of oligochitosan at $75 \mathrm{ppm}$. But when the level of oligochitosan application was increased above $75 \mathrm{ppm}$ then the yield decreased. The highest yield/plant (333.01 g) was observed with $75 \mathrm{ppm}$ oligochitosan. The maximum $(61.75 \mathrm{~cm})$ and minimum $(48.75 \mathrm{~cm})$ plant height were recorded at the levels of $75 \mathrm{ppm}$ and $0 \mathrm{ppm}$ chitosan respectively. The highest number branch/plant (12.97) and fruit/plant (129.78) were showed at $75 \mathrm{ppm}$ whilst the lowest branching number (7.84) and fruit number (97.32) were found at $0 \mathrm{ppm}$ oligochitosan application. The three concentrations of oligochitosan i.e. $50 \mathrm{ppm}, 75 \mathrm{ppm}$ and $100 \mathrm{ppm}$ showed almost the same value than that of $0 \mathrm{ppm}$ and $25 \mathrm{ppm}$. In table-4, it was showed that the highest fruit width was observed at $75 \mathrm{ppm}$ comparing to other concentrations of oligochitosan application. Among the treatments, $75 \mathrm{ppm}$ showed the best for 50 number of chilli weight (125.42 g) comparing to other treatments studied. From the result, it is obvious that chitosan has better effect in chilli yield. It is also observed that oligochitosan application enhance luxurious plant growth and improved fruit yield. Therefore, it is suggested that foliar application of oligochitosan with optimum dose level at different growth stage could increase chilli production per unit area. 
Table 4 Effect of foliar application of oligochitosan on growth and yield of chilli

\begin{tabular}{|c|c|c|c|c|c|c|c|}
\hline $\begin{array}{l}\text { Level of } \\
\text { oligochitosan } \\
\text { application } \\
\text { (ppm) }\end{array}$ & $\begin{array}{l}\text { Plant } \\
\text { height } \\
(\mathrm{cm})\end{array}$ & $\begin{array}{l}\text { Branch/ } \\
\text { plant } \\
\text { (no.) }\end{array}$ & $\begin{array}{l}\text { Fruit/plant } \\
\text { (no.) }\end{array}$ & $\begin{array}{l}\text { Fruit length } \\
(\mathrm{cm})\end{array}$ & $\begin{array}{l}\text { Fruit width } \\
\text { (cm) }\end{array}$ & $\begin{array}{l}\text { Weight of } \\
50 \text { chilli } \\
\text { (g) }\end{array}$ & $\begin{array}{l}\text { Yield/ } \\
\text { plant } \\
\text { (g) }\end{array}$ \\
\hline 0 & 48.75 e & $7.84^{c}$ & $97.32^{c}$ & $7.92 \mathrm{~b}$ & $0.57^{c}$ & $88.26^{e}$ & 181.68 \\
\hline 25 & $52.55^{d}$ & $8.93 \mathrm{bc}$ & $100.25 \mathrm{c}$ & $8.36^{b}$ & $0.61 \mathrm{bc}$ & $93.45^{d}$ & 191.72 \\
\hline 50 & $57.22^{c}$ & $9.92 \mathrm{~b}$ & $111.72 \mathrm{~b}$ & $10.56^{a}$ & $0.68 \mathrm{ab}$ & $103.44^{c}$ & 325.16 \\
\hline 75 & $61.75^{a}$ & 12.97 a & $129.78 \mathrm{a}$ & $11.23^{a}$ & $0.71^{\mathrm{a}}$ & $125.42^{\mathrm{a}}$ & 333.01 \\
\hline 100 & $59.50^{b}$ & $12.35^{\mathrm{a}}$ & $117.38 \mathrm{~b}$ & $10.64^{a}$ & $0.70 \mathrm{ab}$ & $107.41^{b}$ & $282.94^{c}$ \\
\hline F-test & $* *$ & $* *$ & $* *$ & $* *$ & $* *$ & $* *$ & $* *$ \\
\hline CV\% & 1.34 & 9.91 & 3.31 & 10.16 & 7.01 & 1.63 & 1.20 \\
\hline
\end{tabular}

In table-5, the genotypic coefficient of variances (gcv) in case of plant height, branch/plant, fruits/plant, fruit length, fruit width, weight of 50 chilli and yield/plant were observed $49.36 \mathrm{~cm}, 43.07,151.86,19.20 \mathrm{~cm}, 1.06 \mathrm{~cm}, 199.11 \mathrm{~g}$ and 1982.10 g respectively. And the phenotypic coefficient of variance (pcv) in plant height, branch/plant, fruits/plant, fruit length, fruit width, weight of 50 chilli and yield/plant were found to $50.25 \mathrm{~cm}, 53.27,164.03,30.18 \mathrm{~cm}, 3.64 \mathrm{~cm}, 201.84$ $\mathrm{g}$ and $1985.88 \mathrm{~g}$ respectively.

Table 5 Study of PCV and GCV in chilli by foliar application of oligochitosan

\begin{tabular}{llllllll}
\hline & $\begin{array}{l}\text { Plant } \\
\text { height } \\
\text { (cm) }\end{array}$ & $\begin{array}{l}\text { Branch/ } \\
\text { plant } \\
\text { (no.) }\end{array}$ & $\begin{array}{l}\text { Fruit/ } \\
\text { plant } \\
\text { (no.) }\end{array}$ & $\begin{array}{l}\text { Fruit } \\
\text { length } \\
\text { (cm) }\end{array}$ & $\begin{array}{l}\text { Fruit } \\
\text { width } \\
\text { (cm) }\end{array}$ & $\begin{array}{l}\text { Weight of } \\
\mathbf{5 0} \text { chilli } \\
\text { (g) }\end{array}$ & $\begin{array}{l}\text { Yield/ } \\
\text { plant } \\
\text { (g) }\end{array}$ \\
\hline GCV & 49.36 & 43.07 & 151.86 & 19.20 & 1.06 & 199.11 & 1982.10 \\
PCV & 50.25 & 53.27 & 164.03 & 30.18 & 3.64 & 201.84 & 1985.88 \\
\hline \multicolumn{7}{r}{ PCV= Phenotypic co-efficient of variance; GCV = Genotypic co-efficient of variation }
\end{tabular}

Table 6 Study on correlation of oligochitosan with different parameters in chilli

\begin{tabular}{|c|c|c|c|c|c|c|c|c|}
\hline & $\begin{array}{l}\text { Treatment } \\
\text { (ppm) }\end{array}$ & $\begin{array}{l}\text { Plant } \\
\text { height } \\
\text { (cm) }\end{array}$ & $\begin{array}{l}\text { Branch/ } \\
\text { plant } \\
\text { (no.) }\end{array}$ & $\begin{array}{l}\text { Fruit/ } \\
\text { plant } \\
\text { (no.) }\end{array}$ & $\begin{array}{l}\text { Fruit } \\
\text { length } \\
(\mathrm{cm})\end{array}$ & $\begin{array}{l}\text { Fruit } \\
\text { width } \\
\text { (cm) }\end{array}$ & $\begin{array}{l}\text { Weight of } \\
50 \text { chilli } \\
\text { (g) }\end{array}$ & $\begin{array}{l}\text { Yield/plant } \\
\text { (g) }\end{array}$ \\
\hline Treatment (ppm) & 1 & & & & & & & \\
\hline Plant height $(\mathrm{cm})$ & 0.657 & 1 & & & & & & \\
\hline Branch/plant (no.) & 0.515 & 0.639 & 1 & & & & & \\
\hline Fruit/plant (no.) & 0.599 & 0.733 & 0.089 & 1 & & & & \\
\hline Fruit length $(\mathrm{cm})$ & 0.271 & -0.433 & -0.135 & -0.180 & 1 & & & \\
\hline Fruit width $(\mathrm{cm})$ & 0.315 & -0.035 & -0.588 & 0.557 & 0.428 & 1 & & \\
\hline Weight of 50 chilli (g) & 0.710 & 0.734 & 0.287 & 0.917 & 0.060 & 0.489 & 1 & \\
\hline Yield/plant (g) & 0.749 & 0.680 & 0.402 & 0.686 & 0.244 & 0.353 & 0.817 & 1 \\
\hline
\end{tabular}


In table-6, it was showed that treatments were positively linear correlated with all the parameters observed. This indicated that the values of these parameters increased with the increasing dose levels of oligochitosan. Fruit length and fruit width were observed positively weak linear correlated with the treatments. Branch/plant and fruit/plant were found positively moderate linear correlated with treatments. This table also showed that other parameters were showed positively linear correlation with the treatment. The strong correlation was found in yield/plant.

\section{Discussion}

In the present investigation, foliar application of oligochitosan with different levels @25 ppm, @50 ppm, @75 ppm and @100 ppm has been found positive effect on plant height, leaves/plant and branch/plant in tomato plant. In case of chilli, it was observed that plant height, branch/plant, fruit/plant showed also positive effect with the application of different levels of oligochitosan. Many investigators reported that using oligochitosan as foliar spray increased vegetative growth, yield and quality of vegetable crops [27-29]. Algam et al., (2010) found that chitosan was able to enhance the growth and development of tomato plants [30]. These are in agreement with the present investigation. In case of tomato, results indicated that average fruit weight, fruit/plant and yield/plant increased with the increasing trends of oligochitosan application up to $50 \mathrm{ppm}$. Average fruit weight, number of fruit/plant of tomato and chilli showed luxurious growth and development in oligochitosan treated plants than control plants. This might be due to the fact that optimum levels of oligochitosan enhance to produce maximum yield. Similar result also reported by El-Miniawy et al., (2013) [31]. In case of tomato, the maximum yield $2.48 \mathrm{~kg} /$ plant was achieved by applying oligochitosan @50ppm whilst the control yielded $1.90 \mathrm{~kg} /$ plant. This is an important intimation in this study. In case of chilli, the maximum yield $333.01 \mathrm{~g} /$ plant was achieved by applying chitosan level at $50 \mathrm{ppm}$ whilst the control was $181.68 \mathrm{~g} / \mathrm{plant}$. These are also similar to the crop plant such as tomato, orka and wheat [32-34]. These are similar to those reported by earlier literature [15, 30]. Mondal et al., [35] reported that the number of effective flower initiation and flowers/plant were highest in chitosan (25-75 mg L-1) applied summer tomato plants comparing to control plants. Reports were also available in soybean and rice plants where chitosan increased plant height, branch and leaf number over control plant [36-37]. Spraying with chitosan at different developmental stages in strawberry produced fruits with increased shelf life [38]. This indicates that chitosan has versatile effect in crop plant i.e., growth, development and post-harvest improvement. In our study, data are showed significantly different among the treatments (table-1\& table-4). On the contrary, Pięta et al. (2006) obtained statistically non-significant data by foliar application of oligochitosan in soybean plant [39]. The dissimilar results are due to the effect of different crop plant studied. Besides, EI-Bassiony et al., (2014) obtained better yield in Chinese cabbage by foliar spraying with oligochitosan [40]. These results are also supported in our present investigation. Genotypic coefficient of variance (gcv) and phenotypic coefficient of variance (pcv) were estimated from analysis of variance which presented in (table-3 and table-5). This reveals that oligochitosan has good impact for crop yield. It was observed that the phenotypic coefficient of variance was greater than the genotypic coefficient of variance. This indicates that the application of oligochitosan has positive effect for the normal growth and development of tomato and chilli plants. In the present investigation, linear correlation (Table 3) showed that plant height, average fruit weight and yield/plant were negatively linear correlated with the treatments. This result is contrasted with the result of Shehata et al., (2012) [41]. The author reported that others parameters of tomato such as leaves/plant, branch/plant, days to flowering, and fruit/plant were found positively correlated with the treatments. The similar results were reported by Mondal et al., (2012) [42]. This is in compliance with the present study. From the present investigation, it could be concluded that oligochitosan has positive impact for normal growth and development of crop plants. It was also found from the study that application of optimum level of oligochitosan improve luxurious growth of the plant and yield and useful for the plant growth and development. Thus, chitosan could be applied in other crop plants to obtain better yield for sustainable agriculture.

\section{Conclusion}

The present study explores that foliar application of oligo-chitosan plays a significant role in growth promotion of tomato and Chilli in terms of plant height, number of flowers, number of fruits, size of single fruit and weight of single fruit. Thus chitosan application could be a promising tool in modern agriculture to ensure food security for increased world population by limiting environmental hazards.

\section{Compliance with ethical standards}

\section{Acknowledgments}

Authors are giving special thanks to scientists of plant Biotechnology and Genetic Engineering Division, Institute of Food and Radiation Biology, Atomic Energy Research Establishment, for providing laboratory facilities to analyze the fruit 
samples. We would also like to show our gratitude to the Monirul Islam (Department of Life Sciences and Systems Biology, Plant Physiology Unit, University of Turin) for sharing his pearls of wisdom with us during the course of this research. We are also immensely grateful to Dr. Md. Humayun Kabir \& Dr. A. N. K. Mamun (Plant Biotechnology and Genetic Engineering Division, Institute of Food and Radiation Biology, Atomic Energy Research Establishment) for comments that greatly improved the manuscript.

\section{Disclosure of conflict of interest}

We declare that there are no conflict of interest in connection with this paper.

\section{References}

[1] Das MR, Hossain T, Sultan MM, Golam SHM and Rahman MS. (2011). Variation growth and yield quality of tomato varieties under different sowing time. Bangladesh Research Publications Jurnal, 6(1), 72-76.

[2] Costa LV, Lopes R, Lopes MTG, de Figueiredo AF, Barros WS and Alves SRM. (2009). Cross compatibility of domesticated hot pepper and cultivated sweet pepper. Crop Breeding and Applied Biotechnology, 9(1), 37-44.

[3] Parle Milind, Kaura Sushila (2012). A hot way leading to healthy stay. International research journal of pharmacy, 3(6), 21-25.

[4] Bosland PW, Votava EJ and Votava EM. (2012). Peppers: vegetable and spice capsicums. Cabi, Ed. Illustrated, 22, 230.

[5] Bose TK, Some MG, Kabi J and Choudhury B. (1967). Vegetable crops, Kalyani Publisher, N. Dilhi. Naya Prakash, Calcutta, 206.

[6] Sharfudin AFM, Siddique MA and Sabji B. (1985). $1^{\text {st }}$ edition, Bangladesh Agricultural University, Mymensigh, 4.

[7] Jones JB, Stall RE and Zitter TA. (1997). Compendium of tomato diseases. The APS press, Minnesota, USA, 4-13.

[8] Zhu JK. (2002). Salt and drought stress signal transduction in plants. Annual review of plant biology, 53(1), 247273.

[9] BBS (Bangladesh Bureau of Statistics). (2015). Agricultural Statistical Year Book of Bangladesh, Statistics Division, Bangladesh Bureau of Statistics, Ministry of planning Govt. of the People's Republic of Bangladesh, Dhaka.

[10] FAO. (2006-07). Description of plantation crops, chapter, 3.

[11] Thakur VK and Thakur MK. (2014). Processing and characterization of natural cellulose fibers/thermoset polymer composites. Carbohydrate polymers, 109, 102-117.

[12] Wojdyła AT. (2004). Chitosan (biochikol 020 PC) in the control of some ornamental foliage diseases. Communications in agricultural and applied biological sciences, 69(4), 705-715.

[13] ChunYan L, GuoRui M and WenYing H. (2003). Induction effect of chitosan on suppression of tomato early blight and its physiological mechanism. J Zhejiang Univ Agric Life Sci, 29, 280-286.

[14] [Patkowska E, Pięta D and Pastucha A. (2006). The effect of Biochikol 020 PC on microorganism communities in the rhizosphere of Fabaceae plants. Polish Chitin Soc. Monograph XI, 171-178.

[15] Górnik K, Grzesik M and Romanowska-Duda B. (2008). The effect of chitosan on rooting of grapevine cuttings and on subsequent plant growth under drought and temperature stress. Journal of Fruit and Ornamental Plant Research, 16, 333-343.

[16] Dias AMA, Cortez AR, Barsan MM, Santos JB, Brett CMA and De Sousa HC. (2013). Development of greener multiresponsive chitosan biomaterials doped with biocompatible ammonium ionic liquids. ACS Sustainable Chemistry \& Engineering, 1(11), 1480-1492.

[17] Dzung NA, Khanh VTP and Dzung TT. (2011). Research on impact of chitosan oligomers on biophysical characteristics, growth, development and drought resistance of coffee. Carbohydrate polymers, 84(2), 751-755.

[18] Al-Hetar MY, Abidin Z, Sariah M and Wong MY. (2011). Antifungal activity of chitosan against Fusarium oxysporum f. sp. cubense. Journal of applied polymer science, 120(4), 2434-2439. 
[19] Lizárraga-Paulín EG, Torres-Pacheco I, Moreno-Martínez E and Miranda-Castro SP. (2011). Chitosan application in maize (Zea mays) to counteract the effects of abiotic stress at seedling level. African Journal of Biotechnology, 10(34), 6439-6446.

[20] Pongprayoon W, Roytrakul S, Pichayangkura R and Chadchawan S. (2013). The role of hydrogen peroxide in chitosan-induced resistance to osmotic stress in rice (Oryza sativa L.). Plant growth regulation, 70(2), 159-173.

[21] Limpanavech P, Chaiyasuta S, Vongpromek R, Pichyangkura R, Khunwasi C, Chadchawan S, Lotrakul P, Bunjongrat R, Chaidee A and Bangyeekhun T. (2008). Chitosan effects on floral production, gene expression, and anatomical changes in the Dendrobium orchid. Scientia horticulturae, 116(1), 65-72.

[22] Hadwiger LA. (2013). Multiple effects of chitosan on plant systems: solid science or hype. Plant science, 208, 4249.

[23] Jabeen N and Ahmad R. (2013). The activity of antioxidant enzymes in response to salt stress in safflower (Carthamus tinctorius L.) and sunflower (Helianthus annuus L.) seedlings raised from seed treated with chitosan. Journal of the Science of Food and Agriculture, 93(7), 1699-1705.

[24] Nguyen Van S, Dinh Minh H, Nguyen Anh D. 2013. Study on chitosan nanoparticles on biophysical characteristics and growth of Robusta coffee in green house. Biocatal. Agric. Biotechnol., 2(4), 289-294.

[25] Khan WM, Prithiviraj B and Smith DL. (2002). Effect of foliar application of chitin and chitosan oligosaccharides on photosynthesis of maize and soybean. Photosynthetica, 40(4), 621-624.

[26] Chibu H, Shibayama H, Mitsutomi M and Arima S. (2000). Effects of chitosan application on growth and chitinase activity in several crops. Marine \& Highland Bioscience Center Report, 12, 27-35.

[27] Abdel-Mawgoud AMR, Tantawy AS, El-Nemr MA and Sassine YN. (2010). Growth and yield responses of strawberry plants to chitosan application. European Journal of Scientific Research, 39(1), 170-177.

[28] Ghoname AA, El-Nemr MA, Abdel-Mawgoud AMR and El-Tohamy WA. (2010). Enhancement of sweet pepper crop growth and production by application of biological, organic and nutritional solutions. Research Journal of Agriculture and Biological Sciences, 6(3), 349-355.

[29] Fawzy ZF, El-Shal ZS, Yunsheng L, Zhu O and Sawan OM. (2012). Response of garlic (Allium Sativum L.) plants to foliar spraying of some bio-stimulants under sandy soil condition. Journal of Applied Sciences Research, 8(2), 770-776.

[30] Algam SAE, Xie G, Li B, YuS, Su T and Larsen J. (2010). Effects of Paenibacillus strains and chitosan on plant growth promotion and control of Ralstonia wilt in tomato. Journal of Plant Pathology, 593-600.

[31] El-Miniawy S, Ragab M, Youssef S and Metwally A. (2013). Response of strawberry plants to foliar spraying of chitosan. Research Journal of Agriculture and Biological Sciences, 9(6), 366-372.

[32] SathiyabamaM, Akila G and Charles RE. (2014). Chitosan-induced defence responses in tomato plants against early blight disease caused by Alternaria solani (Ellis and Martin) Sorauer. Archives of Phytopathology and Plant Protection, 47(16), 1963-1973.

[33] Mondal MMA, Malek MA, Puteh AB, Ismail MR, Ashrafuzzaman M and Naher L. (2012). Effect of foliar application of chitosan on growth and yield in okra. Australian Journal of Crop Science, 6(5), 918.

[34] Wang M, Chen Y, Zhang R, Wang W, Zhao X, Du Y and Yin H. (2015). Effects of chitosan oligosaccharides on the yield components and production quality of different wheat cultivars (Triticum aestivum L.) in Northwest China. Field Crops Research, 172, 11-20.

[35] Mondal MMA, Malek MA, Puteh AB, Ismail MR, Ashrafuzzaman M and Naher L. (2012). Effect of foliar application of chitosan on growth and yield in okra. Australian Journal of Crop Science, 6(5), 918.

[36] No HK, Lee KS, Kim ID, Park MJ, Kim SD and Meyers SP. (2003). Chitosan treatment affects yield, ascorbic acid content, and hardness of soybean sprouts. Journal of food science, 68(2), 680-685.

[37] Lu J, Zhang C, Hou G, Zhang J, Wan C. (2002). The biological effects of chitosan on rice growth Acta. Agric. Shanghai.18, 31-34.

[38] Saavedra GM, Figueroa NE, Poblete LA, Cherian S and Figueroa CR. (2016). Effects of preharvest applications of methyl jasmonate and chitosan on postharvest decay, quality and chemical attributes of Fragaria chiloensis fruit. Food chemistry, 190, 448-453. 
[39] Pięta D, Patkowska E and Pastucha A. (2006). The effect of Biochikol 020 PC on microorganism communities in the rhizosphere of Fabaceae plants. Polish Chitin Soc. Monograph XI, 171-178.

[40] EI-Bassiony AM, Fawzy ZF, EI-Nemr MA and Li Y. (2014). Improvement of growth, yield and quality of two varieties of kohlrabi plants as affected by application of some bio stimulants. East J. Agric. Res, 3(3), $491-498$.

[41] Shehata SA, Fawzy ZF and El-Ramady HR. (2012). Response of cucumber plants to foliar application of chitosan and yeast under greenhouse conditions. Australian Journal of Basic and Applied Sciences, 6(4), 63-71.

[42] Mondal MMA, Malek MA, Puteh AB, Ismail MR, Ashrafuzzaman M and Naher L. (2012). Effect of foliar application of chitosan on growth and yield in okra. Australian Journal of Crop Science, 6(5), 918.

\section{How to cite this article}

Islam M, Kabir H, Mamun ANK, Islam M, Islam M and Das P. (2018). Studies on yield and yield attributes in tomato and chilli using foliar application of oligo-chitosan. GSC Biological and Pharmaceutical Sciences, 3(3), 20-28. 